\title{
When money grows on trees
}

\author{
Protecting forests offers a quick and cost-effective way of reducing emissions, but agreeing a \\ means to do so won't be easy. Mark Schrope reports.
}

\begin{abstract}
lthough chopping and burning trees causes one-fifth of global greenhouse gas emissions, protecting forests has historically been avoided in international climate negotiations ${ }^{1}$. But as the world inches towards agreeing a new - and hopefully effective - climate deal this December in Copenhagen, addressing the issue is being billed as one of the hallmarks of a successful treaty.

It is now largely acknowledged that protecting forests is not only necessary, it could also be the quickest and least expensive path to early and significant emissions reductions. But deciding to do something about it and agreeing on what needs to be done are two very different matters.

The complexity of the issue was what kept it off the table in Kyoto, where the last global climate treaty was agreed in 1997. Discussions at the most recent UN climate change meeting, in Bonn this June, suggest it's still nearly as thorny a topic now as it was then.

The second of five sessions this year that precede the Copenhagen conference, the Bonn meeting kicked off with a moderately sized, 53-page negotiating
\end{abstract}

text, about a third of which focused on the topic of protecting forests. By the end of the meeting, every single statement in the text had been contested to some degree by at least one group or country, and with comments and proposals, the document ballooned to a weighty 250 pages.

\section{EXPANDING OPTIONS}

Some of the issues raised are rooted in serious ethical and environmental concerns, such as how to protect indigenous people and ensure compliance. But much of what was being mulled over boils down to money: adequately addressing deforestation will require a new flow of billions of dollars from developed to developing nations. Developing countries are scrambling to position themselves to receive as much as possible, while developed nations are doing their best to ensure they get what they want from their investments. The result is a complex debate that is likely to grow more heated as countries move from stating their positions to settling on an agreement that everyone can live with beyond December.

And then there's the mammoth task of deciding what to include in such a

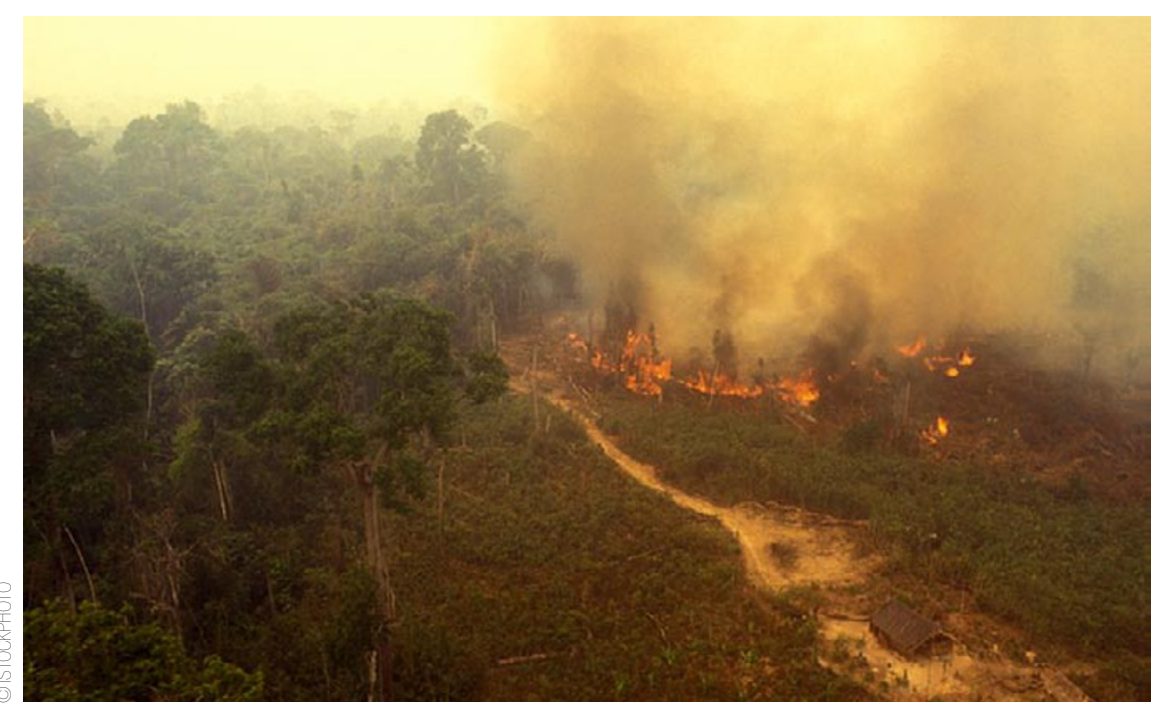

scheme. Initial proposals for 'reducing emissions from deforestation', known as RED, had developed into a plan to reduce emissions from deforestation and forest degradation (REDD) by late 2007, when UN climate talks in Bali called for a decision on forests to be made by 2009 . Now, negotiators are looking at a scheme called REDD Plus that would deal with deforestation and degradation as well as efforts to protect and enhance existing forest carbon stocks.

REDD Plus is certainly the most comprehensive initiative to date, but it may not be the simplest solution. Greenhouse gas emissions from deforestation in Brazil and Indonesia are an order of magnitude higher than in any other country ${ }^{2}$ (Fig. 1), so if the only goal were to achieve the largest emissions reductions as quickly as possible, then all efforts and funds would be focused on ending land clearing in these countries. But the reality is, of course, not so simple, for two key reasons: longevity and political haggling. "Everybody wants to get a piece of the cake," says Thelma Krug, a negotiator for the Brazilian government on climate and forestry issues and a senior scientist with the National Institute for Space Research (INPE) in São José dos Campos. "Now we have to deal with issues that potentially wouldn't be so complex if we were focusing exclusively on reducing deforestation."

But to have a real impact on atmospheric carbon dioxide levels, trees must remain protected for a century or more against fire, resumed logging and clearing, and slower forms of degradation. Likewise, countries such as Guiana and Gabon that are highly forested but have had little deforestation would ideally be aided in staying on development paths that are not dependent on deforestation, lest major new emissions sources emerge.

\section{PERVERSE INCENTIVES}

For now, the term REDD Plus means different things to different countries. While some environmentalists fear the 
Bonn negotiations lost sight of the key deforestation issues, to others REDD Plus is a welcome shift with significant financial implications. Countries such as India and China are especially supportive of the scheme, in large part because they stand to benefit little from REDD alone. Motivated by such goals as reducing flooding and landslides, they've already ended most of their deforestation and instead are now heavily focused on planting trees. What they have done on their own without financial compensation could become a lucrative pursuit for other countries doing the same, only later - a potentially unfair outcome.

"If you're going to reward reductions in deforestation, then shouldn't you also be rewarding ... places like China that have had these enormous investments in [planting trees] over the past decade and are actively removing carbon dioxide?" says Daniel Zarin, a senior advisor on tropical forest carbon strategy for the David and Lucille Packard Foundation in Gainesville, Florida.

REDD Plus could be incorporated into an agreement in such a way that it compensates countries for such efforts. But some fear that defining activities for financial compensation too narrowly or too broadly, without proper checks and balances, would create the incentive for some very bad behaviour. Too narrow a focus on stopping deforestation could encourage countries to resume or begin clear-cutting or logging that they can later halt in order to collect the associated rewards. If reforesting is rewarded without proper constraints in place, however, a standing forest could be cleared, releasing a huge pulse of carbon dioxide, with little penalty as long as the area is replanted.

Environmental groups such as the Ecosystems Climate Alliance (ECA), a consortium of eight non-governmental organizations, were distressed by REDD Plus discussions at Bonn, which they felt were driven too much by industrial interests. "We're going to end up with the potential for clever accounting rather than actually dealing with the problem of mass degradation of the world's forests," says Sean Cadman at the Wilderness Society Australia, an ECA member based in Hobart.

Besides fearing a regime where land clearing is unintentionally encouraged, or at least permitted, they are concerned that sustainable forest management might include logging practices. Even if sanctioned logging is selective and minimal, says Cadman, it is invariably followed by illegal logging and in some cases by land clearing. "Every time
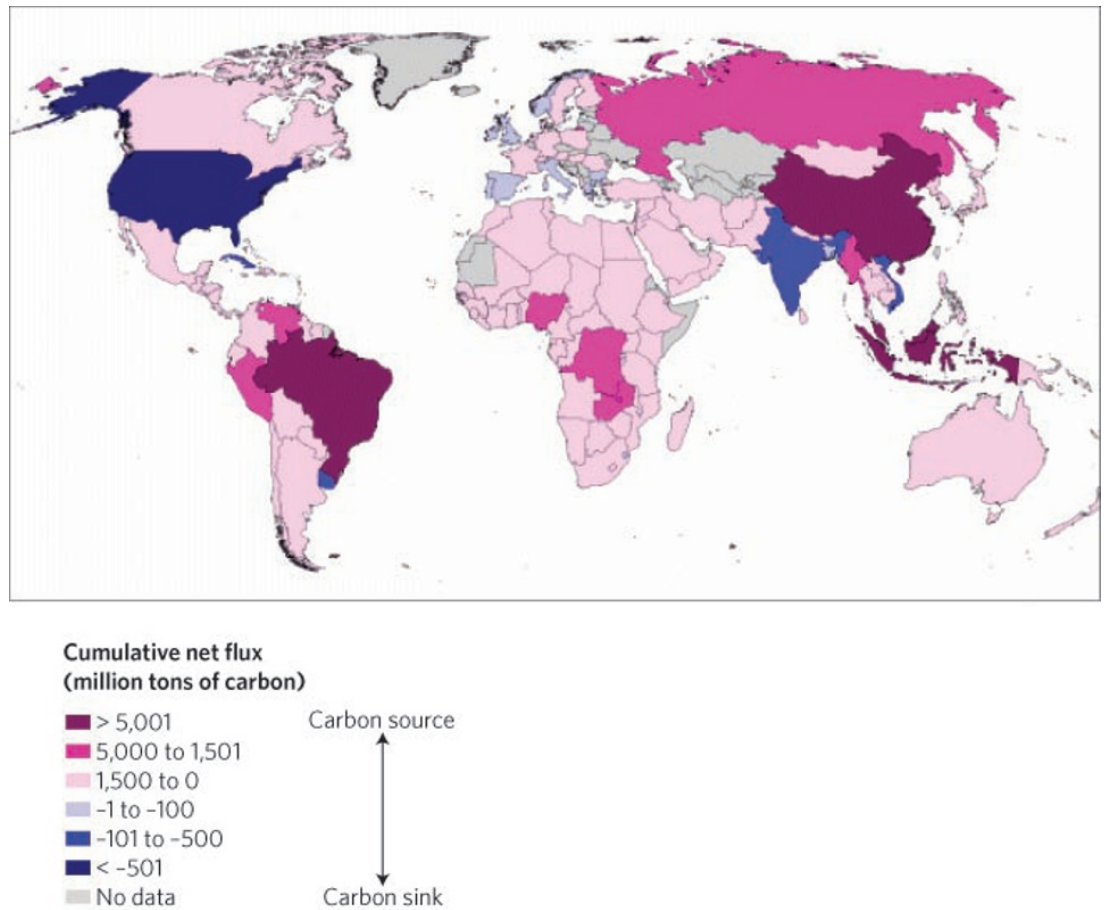

Figure 1 Transforming the landscape. Cumulative net flux of carbon to the atmosphere from changes in land use, 1950-2000 (ref. 4). Courtesy of Earth Trends/World Resources Institute.

the logging industry comes in it's the beginning of the end of the forest and the people that depend on it," he says.

\section{"We're going to end up} with the potential for clever accounting rather than actually dealing with the problem of mass degradation of the world's forests."

\section{Sean Cadman}

Markku Kanninen, a senior scientist at the Center for International Forestry Research in Bogor, Indonesia, opposes language that would encourage logging expansion but says that realistically it needs to continue for now in places where it's an integral part of the economy. "We cannot control all land use only from a climate point of view," he says. "Society needs other things." In the case of logging, he argues, someone will end up doing it somewhere. The question is, says Kanninen, "Through REDD, can we promote doing it in a sustainable way or not?"

Daniel Nepstad with the Woods Hole Research Center in Massachusetts, who has worked for decades on deforestation issues in the Amazon, says that as diverse as the goals and interests involved may be, it is possible to formulate REDD Plus language that will keep everyone happy. One key component endorsed by Australia, Norway and others is a comprehensive accounting of overall carbon emissions and sinks at the national level as a way of determining a country's compensation for REDD-related activities.

Under such a system, selective logging or outright clearing, for instance, would significantly dent a country's overall tally of carbon credits. Planting trees would earn a country credits, but only commensurate with the small amount of carbon storage in young trees, so planting and logging would not be exchangeable.

Past efforts by China, India and others to keep their forests intact could also be rewarded if levels of forested land area were compared with a historic baseline far enough in the past. Ongoing efforts to maintain standing forests could be included in such a system, which would encourage the Guianas and Gabons to continue their conservation work.

\section{DUE DIVIDENDS}

Besides agreeing on the activities eligible for financial compensation, another major sticking point is deciding how the money 
will ultimately be delivered to developing nations. The most likely options are a global cap-and-trade system or a direct fund paid into by developed countries.

Brazil, which has already enacted its own plan for ending deforestation, is an outspoken opponent of any form of market system. Specifically, it argues that if reducing deforestation becomes a source of credits, rich nations will buy them as offsets instead of reigning in their own emissions. "Under an offsetting mechanism, due to its nature, the gain to the climate is null," says Krug. That fear - that a REDD offsetting system would, to a degree, let developed countries off the hook - is a persistent one. It was the chief concern that kept developing nations from supporting inclusion of a REDD component in the Kyoto Protocol.

If parties to a new treaty agree to an offset system despite opposition, a related and pervasive worry is that any market established could be flooded with forestryrelated credits, which would probably be much cheaper than other options. This too could curtail efforts to reduce emissions by other, more expensive means. The problem is not easily solved, but possibilities include imposing set prices on credits or establishing parameters ahead of time for how many total credits could be sold from a given country.

Norway - an established leader in the push for REDD and a major supporter of ongoing REDD work - has put forward a phased approach that offers a compromise between market and fund solutions. This would entail using voluntary funds to support the initial development of muchneeded infrastructure before eventually shifting to compensation based on verified results. This later compensation would probably be handled by an offset system. If the United States and California are successful in their current bids to build cap-and-trade systems with reducing deforestation as a major component, it could push negotiations towards an eventual market system.

Once countries receive their due dividends, an even thornier issue may be ensuring the funds end up in the hands of legitimate recipients. Those most affected by efforts to end deforestation will be indigenous people that depend on forests and the activities that require clearing or degrading them. The fear is that bureaucratic pits could swallow money coming in, leaving little compensation for indigenous groups' economic losses. "The big concern really is that once trees and carbon take on more value, either nations or industries will come in and claim those resources," says Nepstad. This danger was highlighted by a recent violent uprising in Peru after the government tried to open the Amazon to mining, oil and timber development in a way that indigenous people felt stripped them of territorial rights.

\section{"We cannot control all land use only from a climate point of view. Society needs other things." \\ Markku Kanninen}

As strange as it may seem, something as simple as a single letter can have profound implications in international negotiations. One point of debate is whether to refer to "indigenous people" or "indigenous peoples" in a potential Copenhagen treaty. Mentioning "peoples" can be interpreted as conferring - or at least inferring - sovereignty for groups. This is especially troublesome to countries such as the United States and Canada that still have lingering issues in their relationships with native populations. Some problems might be avoided by using REDD language that doesn't reference the UN Declaration on the Rights of Indigenous Peoples (UNDRIP), which key players such as the US have not ratified. But indigenous-group representatives meeting at a conference in Anchorage, Alaska, in April called for climate negotiations to respect the UNDRIP. "We're very hopeful that we can agree on the substance of this and not have to fight through the language issues," says Jonathan Pershing, the US State Department's deputy special envoy for climate change. "I don't think we have to get sidetracked; my sense is there are ways to manage this."

There is no simple solution to the indigenous issues, but there are at least general ideas about how they can be dealt with. Norway's proposed language from Bonn vaguely requires REDD participants to cooperate in good faith with indigenous people and local communities. "Our intention here is that there should be documentation that a country has been in consultation with indigenous peoples," says Audun Rosland, Norway's chief REDD negotiator.

\section{ROAD TO COPENHAGEN}

"I think there is still a long way to go in the negotiations," says Clare Walsh, assistant secretary for international negotiations in Australia's Branch Department of Climate Change in
Canberra. "An awful lot of issues are open to debate." She points out that the real negotiations - getting those hundreds of pages of comments from Bonn whittled back down to a cohesive agreement - have only just begun and will keep delegations busy at the next meeting in Bonn in August and others scheduled before Copenhagen.

Just how much countries will be willing to bend in order to come to an agreement is not clear. Zarin says, “That's the \$64,000 question, isn't it? Who is going to compromise and what those compromises are going to be is really difficult to see" - not least because REDD efforts will ultimately have to be defined within the larger context of an international climate change agreement.

Nonetheless, some are optimistic. "If you get an agreement in Copenhagen, REDD will certainly be an important part of that," says Rosland. Of course, there is no guarantee that there will be a treaty agreement in December. If there is, it's quite likely that the framework will be only broadly defined, with the details to be worked out in coming years, as was the case with Kyoto.

Carlos Nobre from INPE in Brazil says that REDD's fate, along with that of the larger effort, may be determined by the degree to which key countries and their leaders step in to push negotiations forward. "If it is left only to professional diplomats, they will pretty much do what they have been doing for 15 years, which is move in the right direction, but in slow increments," he says. "But perhaps Copenhagen should be revolutionary, not evolutionary. Eventually some of the visionaries will find that this is the time for them to move."

Published online: 13 August 2009

\section{doi:10.1038/climate.2009.78}

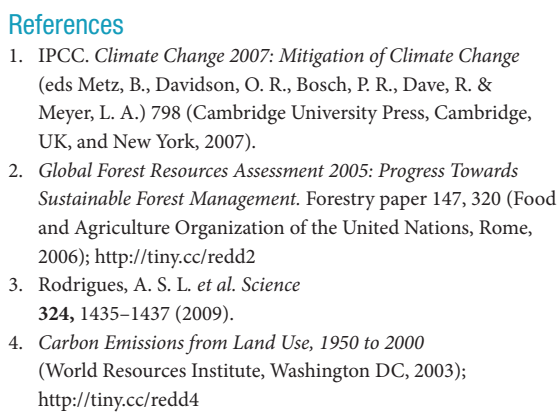

Mark Schrope is a freelance science writer based in Florida. 